\title{
CHRONOSTRATIGRAPHY OF THE VISTULIAN GLACIATION ON THE KUJAWY MORAINE PLATEAU (CENTRAL POLAND) BASED ON LITHOSTRATIGRAPHIC RESEARCH AND OSL DATING
}

\author{
KRZYSZTOF R. PRZEGIĘTKA ${ }^{1}$, ALICJA CHRUŚCIŃSKA ${ }^{1}$, HUBERT L. OCZKOWSKI ${ }^{1}$ \\ and PAWEL MOLEWSKI ${ }^{2}$ \\ 1Institute of Physics, Nicolaus Copernicus University, \\ Grudziądzka 5/7, 87-100 Toruń, Poland \\ 2Institute of Geography, Nicolaus Copernicus University, \\ Gagarina 9, 87-100 Toruń, Poland
}

\begin{abstract}
The subject of the investigations presented here is fixing dilemmatic character (transgressive or recessive) of the Poznan phase of the Vistulian (Weichselian) Glaciation and answering the question about the possibility of lithostratigraphic separation of this phase from the Leszno phase in the region of so called Vistula lob. Here we present the outcomes of the research project carried out on a few tills exposures, which constitute the sedimentological record of the last ice sheet advance on the Kujawy Moraine Plateau. The absolute ages of 17 samples (collected from fluvial deposits uncovered in the geological logs) have been determined by means of the OSL method applying the single aliquots regenerative (SAR) dose protocol. The OSL data are analysed with regard to supposed bleaching conditions at the moment of the last transport and deposition of the material. In conclusion, some remarks on suitability of fluvial sands for OSL dating are made. In most of the investigated sites, there appears to exist only a single till level associated with the main stage of the Vistulian Glaciation. This fact and the results of OSL dating support the hypothesis, that the Poznan phase in Kujawy Moraine Plateau is not a distinct lithostratigraphic unit, but it is a recessive phase of the last glaciation.
\end{abstract}

Keywords: Vistulian Glaciation, OSL dating, OSL bleaching, fluvial sands, Kujawy Moraine Plateau.

\section{INTRODUCTION}

The paper deals with the issue discussed earlier in literature (among the others: Galon, 1956; Mojski, 1968; Kozarski, 1988, 1995; Marks, 1988; Stankowska and Stankowski, 1991; Wysota, 2002; Wysota et al., 2006) and it refers to the character (transgressive or recessive) of the Poznan phase of the Vistulian (Weichselian) Glaciation and, as a consequence, the lithostratigraphic separation of this phase from the Leszno phase of the last glaciation within the so-called Vistula lobe (Fig. 1a).

In the region of the Lower Vistula there is evidence on separateness of the above phases (Wysota, 2002). This

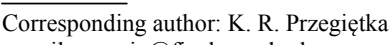

e-mail: przeciu@fizyka.umk.pl

ISSN 1897-1695 (online), 1733-8387 (print) @ 2008 GADAM Centre

Institute of Physics, Silesian University of Technology.

All rights reserved. thesis is supported by the luminescence dating of the deposits from the Lower Vistula region (Wysota et al., 2002; Wysota et al., 2006). The cited author (Wysota, 2002) tries to extend his conclusions on the site of the Eem Interglacial in Mikorzyn near Ślesin in the Konin region (Fig. 1b), where the duality of the deposits of the last glaciation is visible (Kozydra and Skompski, 1996; Stankowski et al., 1999). Wysota (2002) also correlates his results obtained for Lower Vistula region with the two separate till beds in the east part of the Płock Basin documented by Skompski (1969) and other researchers. According to Mojski (1984) those till beds correspond with the Poznań and Leszno phases. After Wysota (2002) the correspondence of deposits in the south of the region of the Lower Vistula with the above-mentioned sites proves the Poznan phase is represented by a separate 
a

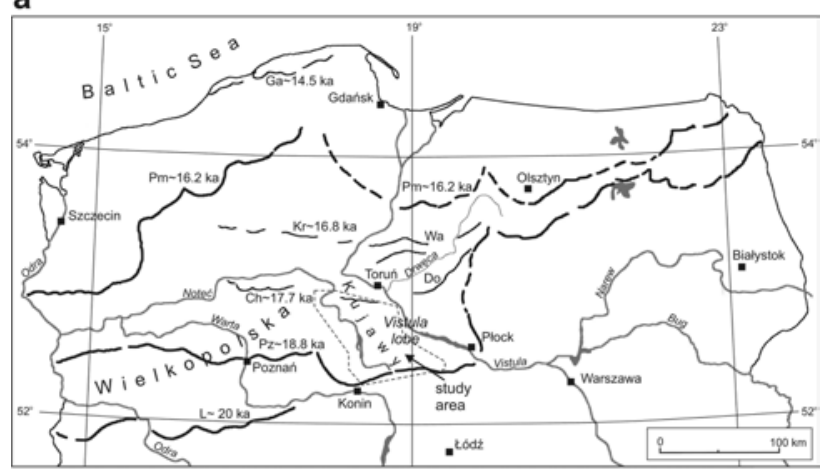

b

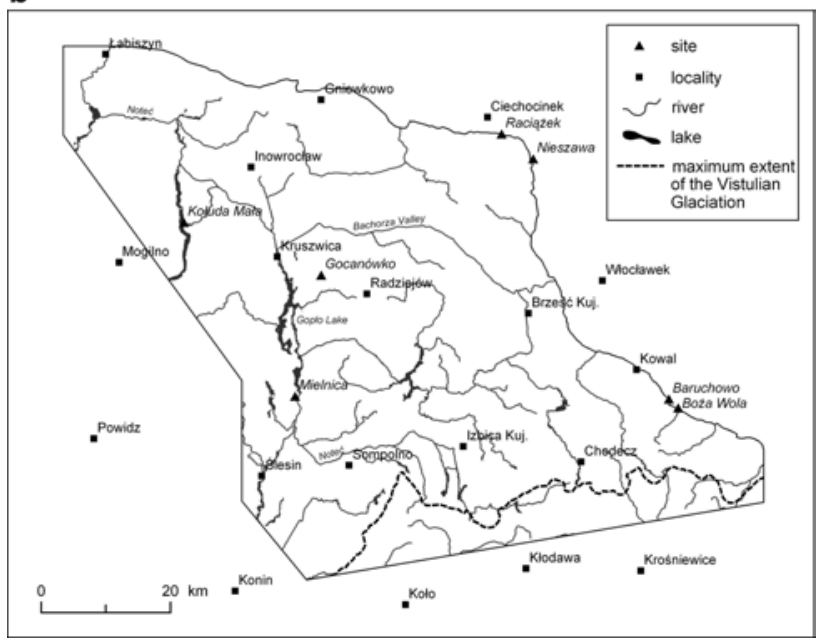

Fig. 1. Study area: a - location against the last ice sheet margins in Poland (after Kozarski, 1995); L - the Leszno phase, Pz - the Poznań phase, Ch, Do - the Chocież and Dobrzyń subphases, Kr, Wa - the Krajna and Wabrzeźno subphases, Pm - the Pomeranian phase, Ga the Gardno phase; $b$ - location of the research sites.

lithostratigraphic unit which is connected with the separate pan-regional ice sheet advance of the main stage of the Vistulian Glaciation.

\section{STRATIGRAPHY OF THE VISTULIAN}

Stratigraphy of the last glaciation in the Kujawy Moraine Plateau, which is located between the Lower Vistula region and the Konin region (Fig. 1a), is based on poorly documented morpho- and lithostratigraphic criteria. This mainly stems from scarcity of the forms and their unclear genesis. According to the various authors, these forms mark the different rank periods of the ice sheet stagnation. Moreover, the tills, which are a sedimentological record of the ice sheet advance, have been inadequately studied. There is very little chronostratigraphic data based on the $\mathrm{C}-14$ or TL methods available on the area.

According to Molewski (2007) there is no evidence the ice sheet advanced onto the Kujawy Moraine Plateau during the Early and Middle Vistulian. The very issue of the existence and extent of the above advances is still being discussed (Wysota, 2002; Makowska, 2004). Thus, the problem of the last glaciation in the studied area is limited to the main stage of the Vistulian Glaciation.
The presently accepted course of the events of the main stage of the Vistulian Glaciation in the Kujawy Moraine Plateau has been based on the Wielkopolska example (Kozarski, 1991a; 1995). It assumes that the Poznań phase is not a separate lithostratigraphic unit, but it is just a stage of the recession of the ice sheet of the Leszno phase. According to Kozarski (1991b) the maximum spread of the Leszno phase was followed by the regression of the ice sheet snout to the new stagnation line in the central part of the Wielkopolska Lowland. To the east of Konin and towards the Vistula, i.e. in the research area, "the snout of the ice sheet of the Poznan phase stretched further due to a positive mass balance" (Kozarski, 1991b). The Poznań phase in the southern part of the Kujawy Plateau, though, might have a character of a local transgression.

Following the opinion of Kozarski (1991b), the sites located within the maximum extent of both phases of the main stage of the Vistula Glaciation cannot be correlated undoubtedly with the results of the research carried out in the Lower Vistula region and interpreted as the evidence of the pan-regional ice sheet advance. Lithostratigraphic separateness of both phases should be sought to the south of the area studied by Wysota (2002), i.e. beyond the zone of the maximum extent of the last glaciation, in northern and central part of the Kujawy Moraine Plateau. The authors of the article have undertaken such research in the area defined above.

\section{METHODS}

\section{Study area}

Stratigraphic research of the deposits from the Vistulian Glaciation in the Kujawy Moraine Plateau was carried out in 2004-2005 at seven research sites (Molewski, 2007). A limited number of the sites stems from the fact that the Kujawy Moraine Plateau generally lacks natural or artificial exposures where full profiles of the deposits of the last glaciation, especially the tills, would be visible. The studied sites are located along the eastern edge of the Kujawy Moraine Plateau (sites at Boża Wola, Baruchowo, Nieszawa, Raciążek), in the slopes of subglacial channels (tunnel valleys), i.e. the subglacial channel of Lake Gopło (the site at Mielnica) and the subglacial channel of Lake Pakoskie (the site at Kołuda Mała), as well as within the area of ground moraine to the east of Lake Gopło (the site at Gocanówko) (Fig. 1b). The detailed lithostratigraphic and sedimentological analyses were carried out (Molewski, 2007). They included the lithofacial analysis followed by the differentiation of the sedimentary units, the analysis of the directional elements (till fabric, palaeocurrents and kinematical indicators), lithological and petrographic analysis (grain size composition, carbonate content, quartz grain roundness and petrographic composition of gravels in tills), as well as the OSL dating of the deposits. The detailed results of both sedimentological and lithostratigraphic research carried out at the Nieszawa site have already been published (Wysota et al., 2004; Molewski and Wysota, 2006). 

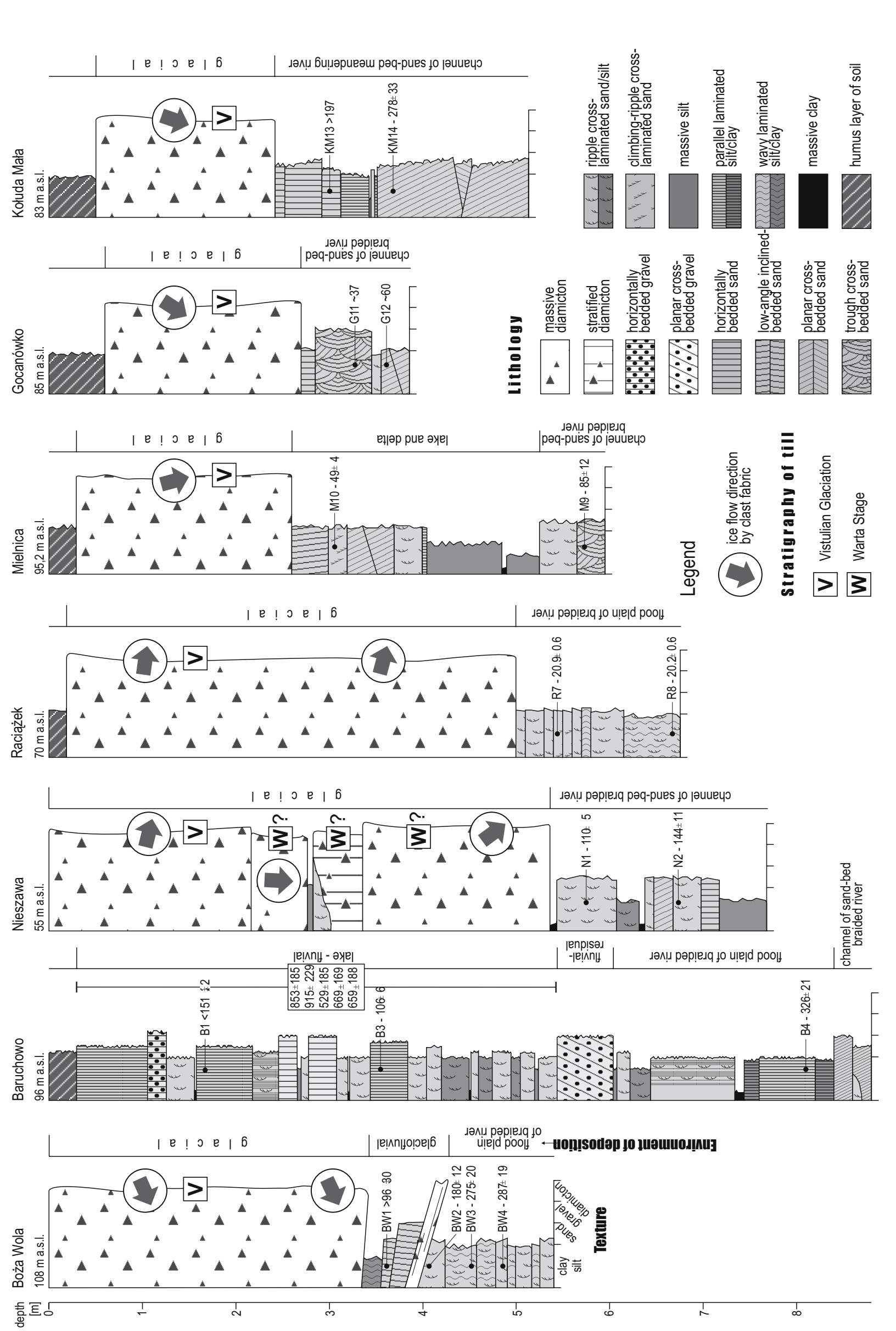


\section{Sample preparation and equipment}

The absolute ages of 17 samples (Table 1, 2 and Fig. 1, 2) have been determined by means of the OSL method applying the single aliquots regenerative (SAR) dose protocol (Murray and Wintle, 2000). Although in some cases only 2 samples were dated per one site, the

Table 1. Geological characteristics of the samples and analysis of OSL results.

\begin{tabular}{|c|c|c|c|c|}
\hline Site & $\begin{array}{c}\text { Sample } \\
\text { name }\end{array}$ & $\begin{array}{l}\text { Lithological features } \\
\text { of sampled material }\end{array}$ & $\begin{array}{c}\text { Relative } S D^{*} \\
(\%)\end{array}$ & $\begin{array}{c}\text { Conclusions from OSL results } \\
\text { \& remarks on environmental conditions of bleaching }\end{array}$ \\
\hline \multirow[t]{3}{*}{ Boża Wola } & BW1 & $\begin{array}{l}\text { Sample taken from gla- } \\
\text { ciofluvial (or fluvial) sands } \\
\text { and gravel. Structure of this } \\
\text { deposit shows glacitectonic } \\
\text { disturbances. }\end{array}$ & 29 & $\begin{array}{l}\text { Relatively wide spread of natural OSL signal causes high } \\
\text { uncertainty of ED value. The reason could be both: poor } \\
\text { bleaching due to glaciofluvial origin (limited day-light exposure) } \\
\text { and/or the sampled material consists of grains of various ages } \\
\text { ranging from ( } 96 \pm 30 \text { ) ka to } \sim 160 \text { ka and mixed together by } \\
\text { glacitectonic disturbances. }\end{array}$ \\
\hline & $\begin{array}{l}\text { BW2 } \\
\text { BW3 }\end{array}$ & $\begin{array}{l}\text { These samples represent } \\
\text { one thick series of fluvial } \\
\text { sediments, built of ripple } \\
\text { cross-laminated fine sands }\end{array}$ & 15 & $\begin{array}{l}\text { The relatively compact histograms of natural OSL signal sug- } \\
\text { gest good bleaching conditions during transport and sedimen- } \\
\text { tation. Well bleached material was deposited in rather shallow } \\
\text { and relatively slow-flowing river (flood plain of braided river). }\end{array}$ \\
\hline & BW4 & $\begin{array}{l}\text { and wavy laminated silty } \\
\text { sands. }\end{array}$ & 22 & The self-consistent OSL age sequence was achieved. \\
\hline \multirow[t]{3}{*}{ Baruchowo } & B1 & $\begin{array}{l}\text { Three samples of three } \\
\text { series of fluvial sediments. }\end{array}$ & 31 & $\begin{array}{l}\text { The material was deposited in rather shallow river (flood plain } \\
\text { of braided river) with relatively slow transport (B4) or experienc- }\end{array}$ \\
\hline & B3 & $\begin{array}{l}\text { They are mainly built of } \\
\text { parallel laminated fine sands }\end{array}$ & 27 & $\begin{array}{l}\text { ing periodical variations in flow regime ( } \mathrm{B} 1 \text { and } \mathrm{B} 3 \text { ). What } \\
\text { more, quartz grains from sample } \mathrm{B} 4 \text { exhibits features of ae- }\end{array}$ \\
\hline & B4 & $\begin{array}{l}\text { and silts (B4), while B1 and } \\
\text { especially B3 has admixture } \\
\text { of coarse sands. }\end{array}$ & 18 & $\begin{array}{l}\text { olian transport, which must have occurred prior to the fluvial } \\
\text { sedimentation, improving optical bleaching. Relatively broad } \\
\text { and symmetric shape of natural OSL signal distribution is } \\
\text { responsible for rather high uncertainty of ED assigned for } \\
\text { sample B1. This could be connected with periodical variations } \\
\text { in flow regime and relatively short transport. It is also reflected } \\
\text { by the inversion of OSL ages for samples B1 and B3. }\end{array}$ \\
\hline \multirow[t]{3}{*}{ Mielnica } & M10 & $\begin{array}{l}\text { The sediment is built of fine } \\
\text { and medium-grained sands } \\
\text { showing climbing-ripple }\end{array}$ & 30 & $\begin{array}{l}\text { The distribution of natural OSL signal has rather broad shape } \\
\text { suggesting, that probably the upper part of delta of a river with } \\
\text { relatively shallow water but rather massive transport didn't }\end{array}$ \\
\hline & & $\begin{array}{l}\text { cross-laminated and low- } \\
\text { angle inclined-bedded } \\
\text { structure. }\end{array}$ & & $\begin{array}{l}\text { assure appropriate conditions for efficient bleaching. The low } \\
\text { uncertainty of ED value was achieved only by careful selection } \\
\text { of OSL results. }\end{array}$ \\
\hline & M9 & $\begin{array}{l}\text { The sample taken from } \\
\text { coarse sands and gravel } \\
\text { forming fluvial sediments } \\
\text { showing trough cross- } \\
\text { bedded structure. }\end{array}$ & 66 & $\begin{array}{l}\text { The histogram of natural OSL signal exhibits extremely vide } \\
\text { and asymmetric distribution of results, indicating serious prob- } \\
\text { lems with bleaching efficiency. The day-light exposure was } \\
\text { probably limited due to quite deep water and fast transport in } \\
\text { channel of a river. ED value is accompanied by rather high } \\
\text { uncertainty. }\end{array}$ \\
\hline \multirow[t]{2}{*}{ Gocanówko } & G11 & $\begin{array}{l}\text { Both samples represents } \\
\text { one fluvial series built of }\end{array}$ & 40 & $\begin{array}{l}\text { For both samples there are very wide spreads of natural OSL } \\
\text { signal. It causes so high uncertainty of ED values that only }\end{array}$ \\
\hline & G12 & $\begin{array}{l}\text { medium- grained sands, but } \\
\text { G11 has admixture of } \\
\text { gravel, while G12 contains } \\
\text { some finer sand. Sample } \\
\text { G11 shows the trough } \\
\text { cross-bedded and G12 } \\
\text { planar cross-bedded struc- } \\
\text { ture. }\end{array}$ & 82 & $\begin{array}{l}\text { their rough estimations are given. Basing on such data OSL } \\
\text { ages were calculated, which however can't be treated as } \\
\text { absolute ages but rather as very rough approximations. Appar- } \\
\text { ently, the bleaching conditions were very poor in channel of a } \\
\text { river, relatively deep underwater. Furthermore, on the base of } \\
\text { lithological analysis, one can expect quite fast transport in case } \\
\text { of G11 sample. }\end{array}$ \\
\hline \multirow[t]{2}{*}{ Kołuda Mała } & KM13 & $\begin{array}{l}\text { Both samples taken from } \\
\text { medium-grained and fine }\end{array}$ & 26 & $\begin{array}{l}\text { Sample KM13 shows not very wide spread of natural OSL. } \\
\text { Unfortunately, the regeneration doses applied in OSL meas- }\end{array}$ \\
\hline & KM14 & $\begin{array}{l}\text { fluvial sands. For sample } \\
\text { KM14 the planar cross- } \\
\text { bedded structure of sedi- } \\
\text { ment layers was detected. }\end{array}$ & 39 & $\begin{array}{l}\text { urements were not big enough enabling only estimation of } \\
\text { lower level of ED value and OSL age. For sample KM14 rather } \\
\text { high uncertainty of ED comes from diversity of natural OSL } \\
\text { results. Both samples represents channel sediments of mean- } \\
\text { dering river. Especially in case of KM14 one can expect that } \\
\text { deep water and fast transport could cause some problems with } \\
\text { bleaching of the material. }\end{array}$ \\
\hline \multirow[t]{2}{*}{ Nieszawa } & N1 & $\begin{array}{l}\text { Both samples represent one } \\
\text { thick series of fluvial sedi- }\end{array}$ & 22 & $\begin{array}{l}\text { The OSL results exhibit rather compact distribution, suggesting } \\
\text { quite efficient bleaching occurring in relatively shallow and slow }\end{array}$ \\
\hline & N2 & $\begin{array}{l}\text { ments, built of ripple cross- } \\
\text { laminated fine sands. }\end{array}$ & 22 & waters on flood plains of braided river. \\
\hline
\end{tabular}

${ }^{{ }^{2}}$ Relative standard deviation SD (\%) representing wideness of natural OSL signal distribution 
Table 2. OSL dates of deposits from Kujawy Moraine Plateau.

\begin{tabular}{|c|c|c|c|c|c|c|c|c|}
\hline$\overline{\text { Site }}$ & $\begin{array}{l}\text { Sample } \\
\text { name }\end{array}$ & Material & Depth (m) & Lab. No. & $\begin{array}{c}\text { Equivalent } \\
\text { dose } E D(G y)\end{array}$ & $\begin{array}{c}\text { Dose rate } \\
D R \text { (Gy/ka) }\end{array}$ & Age (ka) & Stratigraphy \\
\hline \multirow[t]{4}{*}{$\overline{\text { Boża Wola }}$} & BW-1 & Glaciofluvial sands & 3.50 & TPN1 & $104 \pm 32$ & $1.079 \pm 0.005$ & $>96 \pm 30$ & $?$ \\
\hline & BW-2 & Fluvial sands & 4.00 & TPN2 & $229 \pm 15$ & $1.272 \pm 0.005$ & $180 \pm 12$ & SAALIAN \\
\hline & BW-3 & Fluvial sands & 4.55 & TPN3 & $350 \pm 23$ & $1.272 \pm 0.005$ & $275 \pm 20$ & SAALIAN \\
\hline & BW-4 & Fluvial sands & 4.87 & TPN4 & $365 \pm 24$ & $1.272 \pm 0.005$ & $287 \pm 19$ & SAALIAN \\
\hline \multirow[t]{3}{*}{ Baruchowo } & B-1 & Fluvial sands & 1.30 & T046 & $148 \pm 19$ & $0.979 \pm 0.014$ & $<151 \pm 22$ & $?$ \\
\hline & B-3 & Fluvial sands & 4.30 & T048 & $83 \pm 5$ & $0.781 \pm 0.004$ & $106 \pm 6$ & EARLY VISTULIAN \\
\hline & B-4 & Fluvial silts & 11.50 & T049 & $168 \pm 10$ & $0.516 \pm 0.003$ & $326 \pm 21$ & SAALIAN \\
\hline \multirow{2}{*}{ Mielnica } & $\mathrm{M}-10$ & Deltaic sands & 3.10 & T007 & $83 \pm 6$ & $1.693 \pm 0.007$ & $49 \pm 4$ & MIDDLE VISTULIAN \\
\hline & M-9 & Fluvial sands & 5.75 & T006 & $81 \pm 11$ & $0.945 \pm 0.004$ & $85 \pm 12$ & EARLY VISTULIAN \\
\hline \multirow[t]{2}{*}{ Gocanówko } & G-11 & Fluvial sands & 3.20 & T001 & $\sim 28$ & $0.763 \pm 0.003$ & $\sim 37^{*}$ & VISTULIAN? \\
\hline & G-12 & Fluvial sands & 3.60 & T002 & $\sim 37$ & $0.612 \pm 0.003$ & $\sim 60^{*}$ & VISTULIAN? \\
\hline \multirow[t]{2}{*}{ Kołuda Mała } & KM-13 & Fluvial sands & 2.95 & T003 & $>125$ & $0.634 \pm 0.003$ & $>197$ & SAALIAN \\
\hline & $\mathrm{KM}-14$ & Fluvial sands & 3.70 & T004 & $157 \pm 18$ & $0.565 \pm 0.003$ & $278 \pm 33$ & SAALIAN \\
\hline \multirow[t]{2}{*}{ Nieszawa } & $\mathrm{N}-1$ & Fluvial sands & 5.75 & T043 & $200 \pm 9$ & $1.810 \pm 0.010$ & $110 \pm 5$ & EARLY VISTULIAN? \\
\hline & $\mathrm{N}-2$ & Fluvial sands & 6.60 & T044 & $115 \pm 9$ & $0.796 \pm 0.003$ & $144 \pm 11$ & SAALIAN \\
\hline \multirow{2}{*}{ Raciążek } & R-7 & Fluvial sands & 5.45 & TPN5 & $39.2 \pm 1.2$ & $1.874 \pm 0.009$ & $20.9 \pm 0.6$ & LATE VISTULIAN \\
\hline & R-8 & Fluvial sands & 6.70 & T005 & $37.1 \pm 1.1$ & $1.840 \pm 0.009$ & $20.2 \pm 0.6$ & LATE VISTULIAN \\
\hline
\end{tabular}

${ }^{*}$ mean value from numerous aliquots with a large $E D$ scatter

presented results are the first absolute ages from Kujawy Moraine Plateau. Moreover, the results obtained for all the sites seem coherent and enable drawing general conclusions for the whole region.

The sand grains of the diameters from the range (0.100-0.200) $\mathrm{mm}$ were extracted from fluvial sands with the help of wet sieves. Then samples were cleaned with perhydrol $\left(38 \% \mathrm{H}_{2} \mathrm{O}_{2}\right.$ for at least 1 hour or until the reaction was finished) and hydrochloric acid $(10 \% \mathrm{HCl}$ for at least 1 hour or until reaction became quiet) to remove organics and calcite, subsequently rinsed with distilled water and ethanol and dried. After that the quartz grains of density between $2.61 \mathrm{~g} / \mathrm{cm}^{3}$ and $2.70 \mathrm{~g} / \mathrm{cm}^{3}$ were extracted using floatation method (heavy liquids prepared with solutions of sodium polytungstate). Then quartz grains were etched in hydrofluoric acid $(40 \% \mathrm{HF}$ for 40 minutes), which removed the outer layer of grains and etched out any remains of feldspar in the samples. The etching process was stopped with help of hydrochloric acid $(10$ minutes in $10 \% \mathrm{HCl})$, then samples were rinsed with distilled water, ethanol and dried. The purity of samples was checked by routine IR OSL tests. After applying laboratory dose no IR OSL signal was observed that confirms the absence of feldspar contaminations in the samples.

The Riso reader, model TL/OSL-DA-12 equipped with a xenon lamp and excitation filter pack GG-420 (410-580 nm) for stimulation and PM with U-340 filter (290-370 nm) for detection was used for OSL measurements (Bøtter-Jensen and Duller, 1992). The beta source $\left({ }^{90} \mathrm{Sr} /{ }^{90} \mathrm{Y}\right)$ with dose rate of $44.5 \mathrm{mGy} / \mathrm{s}$ was applied for irradiations.

The annual dose rates (DR), comprised of beta and gamma radiation, were calculated on the base of gamma spectra measured in laboratory (sample amount of $600 \mathrm{ml}$ ) with help of Canberra System 100 spectrometer equipped with HPGe detector.

\section{OSL-SAR method and $E D$ and $D R$ evaluation}

The OSL method of dating applied to geological deposits determines the particular moment when an event, which could erase previously accumulated luminescence in mineral grains, has taken place. If transport and/or deposition of the material make the grains to be exposed to the daylight, these can reset the luminescence clock. Such process is called optical bleaching. Its efficiency depends on the conditions of the light exposure (durability, intensity of light and its spectrum). Poor and heterogeneous bleaching may result in large spread of natural luminescence OSL data and as consequence cause high uncertainty of the $E D$ value and imprecise OSL age. What is even worse, incomplete bleaching is a source of the overestimation of the age of a deposit. Unfortunately, the real extent of bleaching in nature is usually uncertain. Hence, in case of geological samples, it is important to carefully consider the validity of the assumption about bleaching, when the OSL age is interpreted. The OSL data are analysed with regard to bleaching conditions expected from the environment at the moment of last transport and deposition of the material (Table $\mathbf{1}$ and Fig. 3).

For every sample 24 aliquots (each one containing $5 \mathrm{mg}$ of quartz grains) were used for OSL-SAR measurements $\left(100 \mathrm{~s}\right.$ of stimulation at $\left.125^{\circ} \mathrm{C}\right)$. The tests of preheat temperature were carried out at: $180^{\circ} \mathrm{C}, 200^{\circ} \mathrm{C}$, $220^{\circ} \mathrm{C}, 240^{\circ} \mathrm{C}, 260^{\circ} \mathrm{C}$ and $280^{\circ} \mathrm{C}$, using four aliquots for every specific temperature. On this base the annealing for $10 \mathrm{~s}$ at $240^{\circ} \mathrm{C}$ was chosen as the best preheat procedure. The test doses, applied for monitoring sensitivity changes were fixed on the level of $10 \%$ of expected $E D$ values. For calculations only the beginning part of OSL decay curve (0-1.2 s) was used. The OSL was stimulated by green light for $100 \mathrm{~s}$, and it was checked out, that it is enough to totally bleach OSL signal to the PM background level. After bleaching the recovery tests were 

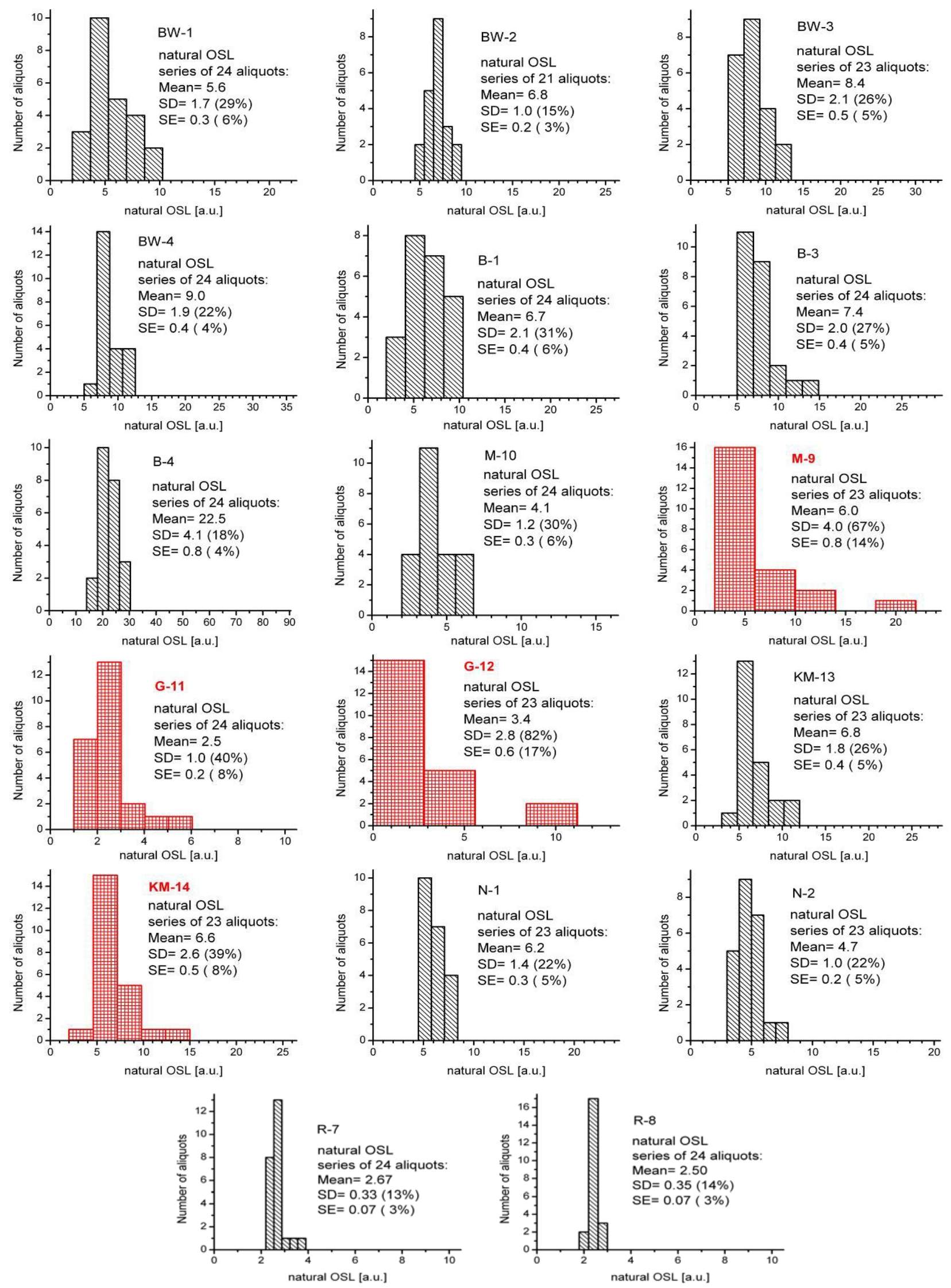

Fig. 3. The histograms showing distributions of calibrated natural OSL signal (corrected for aliquot to aliquot variations of OSL intensity). For each aliquot the natural OSL signal was obtained by integrating natural OSL decay curve in the range of the first 1.2 seconds. Then, natural OSL signal was calibrated by dividing this value by the sum of light calculated for the first 1.2 seconds from OSL decay curve obtained after applying the test beta dose. Standard preheat (for $10 \mathrm{~s}$ at $240^{\circ} \mathrm{C}$ ) was performed prior to read out of both the natural and calibration OSL curves (at $125^{\circ} \mathrm{C}$ ). SD denotes for standard deviation and SE is standard error. The poorly bleached samples are as follows: M-9, G-11, G-12 and KM-14. 
carried out. The results were in good accordance (in the range of $4 \%$ ) with values of given laboratory dose. Beside recovery tests, the reliability of obtained ED results was monitored with help of recycling ratio. The recycling ratio was obtained during routine SAR measurements for repeated regenerative dose value and aliquots exhibiting incorrect recycling ratio values (usually less than 4 aliquots) were not taken into account for averaging $E D$ values. The regeneration doses were fixed to cover the range around $E D$ value, and the growth curve was constructed using four points.

Calculations of $D R$ were based on the activities of usually 15 isotopes (anyway more than 12). The correction for water content and the component of cosmic radiation were taken into account (Oczkowski and Przegietka, 1998; Oczkowski et al., 2000).

The final uncertainty in OSL age estimation (Table 2) is mainly influenced by the standard error of the mean $E D$ value, calculated by averaging the results obtained for individual aliquots.

\section{RESULTS AND DISCUSSION}

Most of the analysed geological logs contain series of fluvial deposits accumulated in the environments of the sand-bed braided rivers (channel and overbank subenvironments; Fig. 2). The Mielnica site is the only one which contains lacustrine and deltaic deposits, while the Kołuda Mała site contains the deposits of a sand-bed meandering river. At six sites the upper deposits contain a moraine till cover. At the Baruchowo site the till has been denuded and is presently found at the background of the investigated exposure. This till, which is about 1 metre thick, makes one bed, both in terms of its age and facies. At the site of Boża Wola the deposits which underlie the till show partly glacitectonic disturbances, which have been already investigated by Roman (2003).

The deposits described above, predominantly the fluvial sands, were the source of 17 samples for the OSL dating. The results prove that the deposits were accumulated during the Saale and the Vistulian Glaciations (Table 2).

The deposits exposed at the Baruchowo site have been researched by Roman (2003) and dated using the TL method. The TL results for the sandy silt series of the deposits, found above a layer of fluvial-residual deposits (Fig. 2), showed a vast range of the TL dates:(659 $\pm 188 \mathrm{ka}$ and $669 \pm 169 \mathrm{ka}$ for the lower section of the series; $529 \pm 185 \mathrm{ka}, 915 \pm 229 \mathrm{ka}$ and $853 \pm 185 \mathrm{ka}$ for the upper section of the series). Roman (2003) assumes these deposits were accumulated during the Saale Glaciation. However, presented results of the OSL dating prove that this series is younger and it was probably accumulated during the Early Vistulian. The big discrepancy between older TL dates (Roman, 2003) and much younger OSL dates received by the authors (Table 2) results probably from the worse effectiveness of the bleaching of the TL signal than the OSL signal (Huntley et al., 1985). Highly imprecise TL dates, which are characteristic for the saturation area of TL signal, also suggest insufficient bleaching during the deposit transportation and accumulation.
The sites of Boża Wola and Kołuda Mała show (Fig. 2) a distinct sedimentation hiatus or erosion of the bed deposits (erosive discordance). The till in these sites is underlain by river deposits of Saale Glaciation (Table 2). The Nieszawa site contains the deposits which probably come from Early Vistulian and which overlie the series of the Saale Glaciation. At the other investigated sites the studied deposits underlying till were accumulated during the Early and Middle Vistulian (the Mielnica and Gocanówko sites) as well as Late Vistulian (the Raciążek site).

The youngest dating results, of the highest precision (uncertainty of about $3 \%$ ), were acquired for the deposits underlying till at the Raciążek site: $20.2 \pm 0.6 \mathrm{ka}$ and $20.9 \pm 0.6 \mathrm{ka}$ (Table 2). They unambiguously indicate the main stage of the Vistulian Glaciation.

Lithofacial, structural and petrographic research of the tills as well as the OSL dating proved that besides the Nieszawa site tills, they consist of one bed of till connected with the main stage of the last glaciation. The till is of the same age, but it sometimes differs facially.

At the Nieszawa site four beds of till were distinguished (Wysota et al., 2004; Molewski and Wysota, 2006). The fact that the three lower beds of till differ from the highest bed in terms of the petrographic composition of their gravels and a clearly diverse directions of the long axis of the clasts proves there exist two, or even three, ice sheet advances. The OSL dating of the deposits underlying this till shows they are closely connected either with the Warta (Warthe) Stage of the Younger Saalian Glaciation and the main stage of the Vistulian Glaciation or, as it was suggested previously, with the Leszno and Poznan phases of the main stage of the last glaciation (Wysota et al., 2004). As far as the three lower till beds are concerned, the petrographic analysis indicates the Warta Stage (Molewski, 2007). Thus, it may be concluded this site also belongs to the ones where the Vistulian Glaciation is represented by one bed of till.

Analysing histograms presenting distributions of natural OSL signals (Fig. 3) with respect to lithology of the dated samples (Fig. 2) some remarks on suitability of geological material for OSL dating can be made (Table 1). All the samples were collected from rather homogenous and thick enough sediments (maybe except sample BW1) so one can assume that for particular sample the only source of diversity of natural OSL signal in a series of aliquots comes from variety of bleaching conditions experienced by grains during last transport and sedimentation. Hence for poorly bleached samples one can expect wide and asymmetrical shapes of the histograms. The high value of percentage standard deviation $S D$ characterising the distribution of natural OSL signal (Fig. 3) can be used as a merit of poorly bleached samples. As a matter of fact one can distinguish two sets of samples:

- Badly bleached samples with $S D$ value above $40 \%$. These are samples from trough cross-bedded sands (M-9 and G-11) and planar cross-bedded sands (G-12 and KM-14). Such lithology is characteristic for sediments whose material was rather rapidly transported and deposited in deep water in a channel of a 
river. Such environment seems to prevent many grains from sufficient bleaching.

- Well bleached samples with $S D$ ranging from $13 \%$ to $31 \%$. These are mainly samples from ripple crosslaminated sands (BW-4, BW-3, BW-2, N-1, N-2 and $\mathrm{R}-8$ ), climbing ripple cross-laminated sands (M-10 and R-7), and also horizontally bedded sands (B-1, B3, B-4 and KM-13). This leads to the conclusion that shallow water and slow transport enables better and more homogenous bleaching.

\section{CONCLUSIONS}

As far as the age is concerned, all the studied sites, excluding the one in Nieszawa, contain only one till bed. It is correlated with the main stage of the Vistulian Glaciation. Such a situation, together with the results of the OSL dating, support the hypothesis that the Poznań phase in the Kujawy Moraine Plateau is not a separate lithostratigraphic unit and shows a recessive character. Accepting the contradictory hypothesis, i.e. the one on the transgressive character of the Poznan phase, would mean assuming that either this transgression was accompanied by intense exaration of ice sheet as well as removal of the proglacial deposits or that the margin of the Leszno phase was much smaller in this area than that of the Poznan phase. In such a case the existing till bed would be a sedimentological record of the Poznan phase of the last glaciation.

The assumption that the maximum extent of the main stage in this area took place not earlier than about $21 \mathrm{ka}$ ago (Stankowska and Stankowski, 1988; 1991; Stankowski, 2000) is based on the TL dating of the deposits in the Konin region. The OSL dates from the Raciążek site show that about $21 \mathrm{ka}$ ago the northern part of the Kujawy Moraine Plateau was free from ice sheet. The above data prove the rate of the ice sheet advance in the main stage of the Vistulian Glaciation in the Kujawy Moraine Plateau was fast.

As a conclusion, general rule for collecting samples from fluvial sediments for OSL dating can be expressed: to choose ripple-marked sands, preferably fine sands with wavy-laminated silts and to avoid trough and planar cross-bedded sands, especially coarse-sized sands with gravel.

\section{ACKNOWLEDGEMENT}

The research project has been financially supported by the Committee for Scientific Research - grant No. 3 PO4E 04024.

\section{REFERENCES}

Bøtter-Jensen L and Duller GAT, 1992. A new system for measuring optically stimulated luminescence from quartz samples. Nuclear Tracks and Radiation Measurements 20(4): 549-553, DOI 10.1016/1359-0189(92)90003-E.

Galon R, 1956. The problem of the last Glaciation in Poland. Reprinted from. Przeglad Geograficzny 28: 75-93.

Huntley DJ, Godfrey-Smith DI and Thewald MLW, 1985. Optical dating of sediments. Nature 313(5998): 105-107, DOI $10.1038 / 313105 \mathrm{a} 0$.
Kozarski S, 1988. Time and dynamics of the last Scandinavian icessheet retreat from northwestern Poland. Geographia Polonica 55: 91-101.

Kozarski S, 1991a. Litostratygrafia górnego plenivistulianu Niziny Wielkopolskiej w granicach ostatniego zlodowacenia: nowe dane i interpretacje (Upper Plenivistulian lithostratigraphy of the Great Poland Lowland (central Poland) within limits of the last glaciation: new data and interpretations). In: Kostrzewski A, ed, Geneza, litologia i stratygrafia utworów czwartorzędowych. Poznań, Wydawnictwo Naukowe UAM Seria Geografia 50: 471-496 (in Polish).

Kozarski S, 1991b. Paleogeografia Polski w Vistulianie (Palaeogeography of Poland in the Vistulian (Weichselian)). In: Starkel L, ed, Geografia Polski - środowisko geograficzne. Warszawa, PWN: 80-105 (in Polish).

Kozarski S, 1995. Deglacjacja północno-zachodniej Polski: warunki środowiska i transformacja geosystemu ( $20 \mathrm{ka} \rightarrow 10 \mathrm{ka} \mathrm{BP})$ (Deglaciation of north-western Poland: environmental conditions and geosystem transformation ( $20 \mathrm{ka} \rightarrow 10 \mathrm{ka} \mathrm{BP})$ ). Dokumentacja Geograficzna 1. Warszawa, IG PAN: 1-82 (in Polish).

Kozydra Z and Skompski S, 1996. Osady międzymorenowe w okolicy Mikorzyna na Wysoczyźnie Konińskiej (Interglacial sediments in the vicinity of Mikorzyn in Konin region, central Poland). Przegląd Geologiczny 44(9): 945-949 (in Polish).

Makowska A, 2004. Nowe badania vistuliańskiej części profilu osadów młodoplejstoceńskich na dolnym Powiślu i wynikające $z$ nich wnioski dyskusyjne (New research of the Vistulian (Weichselian) part of the Upper Pleistocene complex in the Lower Vistula Region (middle-north Poland) and resulting conclusions for discussion). Przeglad Geologiczny 52(10): 953-962 (in Polish).

Marks L, 1988. Relation of substrate to the Quaternary paleorelief and sediments western Mazury and Warmia (Northern Poland). Geologia 14, 1, Wyd. AGH, Kraków: 1-76.

Mojski JE, 1968. Podstawy podziału zlodowacenia północnopolskiego (Principles for division of the North-Polish Glaciation). Kwartalnik Geologiczny 12(3): 665-679 (in Polish)

Mojski JE, 1984. Zlodowacenie północnopolskie (North Poland glaciation). In: Budowa geologiczna Polski, t. 1, Stratygrafia, cz. 3b, Kenozoik - Czwartorzęd. Warszawa, Wydawnictwo Geologiczne: 218-255 (in Polish).

Molewski P and Wysota W, 2006. Litostratygrafia osadów neoplejstocenu w zboczu doliny Wisły w Nieszawie - kontrowersje i nowe dane (Lithostratigraphy of the Neopleistocene deposits at slope of Vistula valley in Nieszawa, central Poland). In: Olszewski A and Chutkowski K, eds., Drogami wędrówek $i$ badań profesora Rajmunda Galona w 100. rocznicę urodzin (1906-2006), Przewodnik sesji terenowych, Ogólnopolski Zjazd Geografów Polskich, 55 Zjazd PTG, Toruń, 13-17 września 2006. Wydawnictwo Turpress: 240-244 (in Polish).

Molewski P, 2007. Neotektoniczne i glacjodynamiczne uwarunkowania wykształcenia plejstocenu Wysoczyzny Kujawskiej (Neotectonic and glaciodynamic conditions for the structure of the Pleistocene in the Kujawy Moraine Plateau, central Poland). Wydawnictwo Naukowe UMK, Torun: 140 pp (in Polish).

Murray AS and Wintle AG, 2000. Luminescence dating of quartz using an improved single-aliquot regenerative-dose protocol. Radiation Measurements 32(1): 57-73, DOI 10.1016/S1350-4487(99)00253$\mathrm{X}$.

Oczkowski HL and Przegiętka K, 1998. Partial Matrix Doses for Thermoluminescence Dating. Physica Scripta 58: 534-537.

Oczkowski HL, Przegiętka K, Lankauf KR, Szmańda JB, 2000. Gamma Spectrometry in Thermoluminescence Dating. Geochronometria 18: 63-68.

Roman M, 2003. Rozwój rzeźby plejstoceńskiej okolic Gostynina (Development of the Pleistocene relief in the vicinity of Gostynin, central Poland). Acta Geographica Lodziensia 84: 1-154 (in Polish).

Skompski S, 1969. Stratygrafia osadów czwartorzędowych wschodniej części Kotliny Płockiej (Stratigraphy of Quaternary deposits of the eastern part of the Płock depression, central Poland). Biuletyn Instytutu Geologicznego 220: 175-258 (in Polish).

Stankowska A and Stankowski W, 1988. Maximum extent of the Vistulian ice sheet in the vicinity of Konin, Poland: a geomorphological, sedimentological and radiometric evidence. Geographia Polonica 55: 141-150.

Stankowska A and Stankowski W, 1991. Morfo- lito- i chronostratygrafia vistulianu we wschodniej Wielkopolsce (Morpho-, litho- 
and chronostratigraphy of the Vistulian (Weichselian) deposits in eastern part of Great Poland, central Poland). In: Kostrzewski A, ed., Geneza, litologia i stratygrafia utworów czwartorzędowych. Poznań, Wydawnictwo Naukowe UAM, Seria Geografia 50: 563571 (in Polish).

Stankowski W, 2000. The geological, paleobotanical and radiometric dating of Quaternary sediments in the region of Konin (eastern Great Poland Lowland). Geologos 5: 175-188.

Stankowski W, Bluszcz A and Nita M, 1999. Stanowiska osadów górnoczwartorzędowych Mikorzyn i Sławoszewek w świetle badań geologicznych, datowania radiowęglowego i termoluminescencyjnego oraz analiz palinologicznych (Sites of Upper Quaternary deposits in Mikorzyn and Sławoszewek (central Poland) on base of geological studies, radiocarbon and thermoluminescence dating and palynological analysis). In: Pazdur A, Bluszcz A, Stankowski W and Starkel L, eds., Geochronologia górnego czwartorzedu Polski $w$ świetle datowania radioweglowego i luminescencyjnego. Wrocław, WIND - J. Wojewoda Publishing Co.: 87-111 (in Polish).

Wysota W, 2002. Stratygrafia i środowiska sedymentacji zlodowacenia wisty $w$ poludniowej części dolnego Powiśla (Stratigraphy and sedimentary environments of the Vistulian (Weichselian) glaciation in the southern part of the Lower Vistula region, middle-north Poland). Rozprawa Habilitacyjna, Wydawnictwo UMK, Toruń: 144 pp (in Polish).

Wysota W, Lankauf KR, Szmańda J, Chruścińska A, Oczkowski HL and Przegiętka KR, 2002. Chronology of the Vistulian (Weichselian) glacial events in the Lower Vistula region, middle-north Poland. Geochronometria 21: 137-142.

Wysota W, Molewski P, Sokołowski RJ and Szmańda J, 2004. Sekwencja glin morenowych zlodowacenia wisły w Nieszawie, NE Kujawy (Sequence of the Vistulian (Weichselian) tills in Nieszawa, NE Kujawy, central Poland). In: Wysota W, ed., Gliny morenowe - typy genetyczne $i$ środowiska depozycji, Terenowe warsztaty sedymentologiczne, Toruń, 6-7 września 2004. Toruń, Wydawnictwo UMK: 11-17 (in Polish).

Wysota W, Piotrowski JA, Murray AS, 2006. The age and the extent of Weichselian ice advances in Poland in the light of OSL dating. In: Johansson P, Lunkka JP, Serala P, eds., Late Pleistocene glacigenic deposits in the central part of the Scandinavia ice sheet, Abstracts, The INQUA Peribaltic Group Field Symposium in Finland, September, 11-15 2006, Geological Survey of Finland, Rovaniemi: 51 